Mitteilungen der Österreichischen Geographischen Gesellschaft, 160. Jg., S. 281-302

(Annals of the Austrian Geographical Society, Vol. 160, pp. 281-302)

Wien (Vienna) 2018, https://doi.org/10.1553/moegg160s281

\title{
THEORETICAL ISSUES IN TOPONYM TYPOLOGY ${ }^{1)}$
}

\author{
István HoFFMANN and Valéria TóTH, both Debrecen (Hungary)* \\ Initial submission / erste Einreichung: 03/2018; revised submission / revidierte Fassung: 10/2018; \\ final acceptance / endgültige Annahme: 11/2018 \\ with 1 figure in the text
}

\section{CONTENTS}

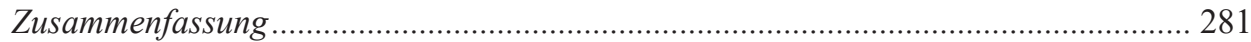

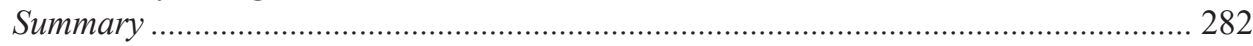

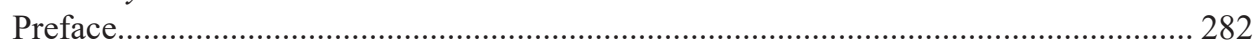

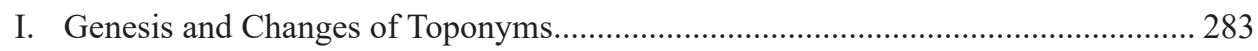

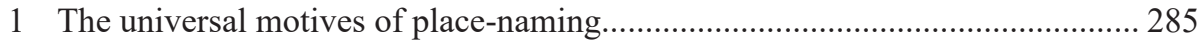

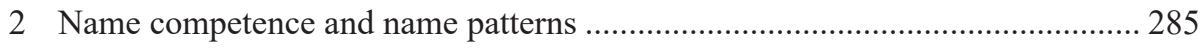

3 The socio-onomastic aspects of place-naming ............................................ 286

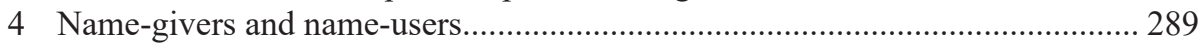

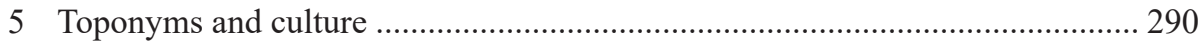

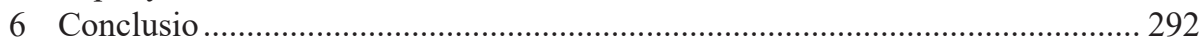

II. A Possible Toponym-Description Model .............................................................. 293

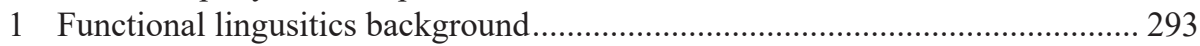

2 The principles of toponym analysis................................................................. 294

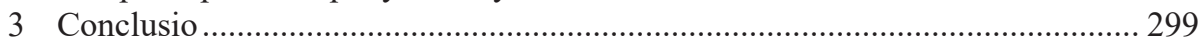

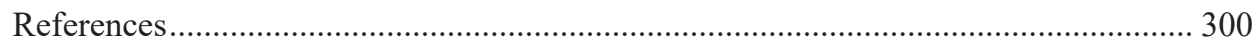

\section{Zusammenfassung}

\section{TheOretische Fragen tOPONYMischer TyPOLOGIE}

Unser Beitrag befasst sich mit zwei Schlüsselfragen: Er spricht erstens die theoretischen Probleme der Genese und Modifikation geographischer Namen an und diskutiert

1) This work was carried out as part of the Research Group on Hungarian Language History and Toponomastics (University of Debrecen - Hungarian Academy of Sciences). The paper is based on the authors' plenary paper that was given at the XXVI International Congress of Onomastic Sciences. The first version of this paper was published in one of the volumes including the papers presented at the congress (Onomastica Uralica 12, Debrecen, 2018). For more details see HoffMann, RÁcZ and Tóth 2017.

* Prof. István Hoffmann Ph.D. DSc and Prof. Valéria Tóth Ph.D. DSc, University of Debrecen, Department of Hungarian Linguistics. H-4028 Debrecen, Egyetem tér 1, Hungary; email: hoffmann.istvan@arts.unideb.hu, toth.valeria@arts.unideb.hu. 
zweitens deren typologische Beschreibung. In beiden Fällen betreten wir Felder, die Gelegenheit zur internationalen Zusammenarbeit und damit zur vergleichenden Analyse toponymischer Systeme in verschiedenen Sprachen bieten.

Was die Genese und Modifikation geographischer Namen betrifft, konzentrieren wir uns im ersten Teil des Beitrags auf die universellen Motive der Namengebung, auf die Rolle der Fähigkeit zur Namengebung sowie von Vorbildern in dieser Hinsicht, auf den sozio-onomastischen Aspekt der Namengebung sowie auf die Beziehungen zwischen geographischen Namen und Kultur.

Im zweiten Teil unseres Beitrags stellen wir den Ansatz und den theoretischen Rahmen unserer Arbeit am System und an der Geschichte ungarischer Toponyme vor. Zuerst widmen wir uns den Grundsätzen, denen wir bei der Analyse von Toponymen folgen. Bei der Beschreibung der Toponyme wenden wir den funktionalen Ansatz an, weil wir der Meinung sind, dass die funktionale Linguistik den geeignetsten theoretischen Rahmen der Toponomastik (und der Onomastik im Allgemeinen) bildet.

Schlagwörter: Namentheorie, toponymische Typologie, ungarische Toponyme, funktionale Linguistik

\section{Summary}

Our paper focuses on two key issues: it addresses the theoretical questions related to the genesis and changes of toponyms and discusses issues concerning the typological description of place names. In both cases, we also touch upon areas that we believe to provide opportunities for international cooperation and thus for the comparative analysis of the toponymic system of different languages.

As for the toponym genesis and toponym changes, we primarily focus on the universal motives of name-giving, the role of name competence and name patterns, the socio-onomastic aspects of name-giving as well as the relations between toponyms and culture.

In the second part of our paper, we introduce the approach and theoretical framework used in our work on the system and history of Hungarian toponyms. First, we need to introduce those principles which we wish to follow in the analysis of toponyms. In the description of toponyms the functional approach is applied as we believe that functional linguistics may serve as the most suitable theoretical framework for toponomastics (and onomastics in general).

Keywords: Name theory, toponym typology, Hungarian toponyms, functional linguistics

\section{Preface}

Our paper introduces two closely-related issues: first, we discuss general questions of name theory related to name giving and name use that have a key role in the analysis of toponyms. This is necessary because there are differing viewpoints in this respect in the various studies concerning name theory. In what follows, we present our view of these issues and how they may be used with regard to name-giving in the Middle Ages. In the 
second part of our paper, a typological perspective is established built on the theoretical questions of the first section and we introduce a universal toponym description model using a functional approach that is suitable for the description and characterisation of the toponym system of any language in any period of time.

\section{Genesis and Changes of Toponyms}

When discussing the genesis of and changes in the toponyms of any language, researchers can fundamentally rely on two types of source materials. The toponymic data themselves are available as direct sources. This source material is represented by the entire modern toponymicon and the toponymic data that have survived in a variety of documents (including medieval charters, maps, and other written linguistic records). Besides this, however, one can also rely on the general findings of name theory as an indirect source regarding place-naming and name usage when looking for information on the genesis and changes of toponyms in a particular era. In our paper we introduce findings on place-naming, name usage, and name changes from toponymic data recorded in both modern language and medieval sources, building on the general principles of name theory. The data studied and used as illustrations are Hungarian toponyms, yet the conclusions drawn also have implications for onomastics in general.

As the statement of the problem, we start our overview with data from medieval charters as through their explanation we can highlight various disputed issues related to the field (often reaching well beyond the scope of onomastic research). Then, we will introduce those general (in our opinion: universal) name theory tenets on the basis of which we can successfully complete the linguistic analysis of specific name data with regard to name-giving and name changes for any era (and in any languages) in the history of the toponymic system. Meanwhile, we also attempt to use the modern toponymic corpus as it enables us to study the various processes while eliminating the temporal distance.

We present the general questions related to name-giving, name usage, and name changes through problems presented by toponymic data taken from four early, $11^{\text {th }}$-century charters representing the earliest age of Hungarian written records. Such name data are not informative primarily as individual names from the perspective of the subject matter at hand, but may become instructive because they also bear the general features of name types. The selected four toponyms represent different categories from the perspective of their genesis and typology, and this circumstance fundamentally defines not only the course of their linguistic life, but also the conclusions that may be drawn from them.

In order to specify what kind of general problems these specific cases represent for name theory, first of all, we have to see how their position as well as their value as linguistic and possibly ethnic sources are regarded in the fields of onomastics and history, the latter also building on the findings of the former.

Balaton is the largest lake in Eastern Europe. Its name has been used in the same structural form during its entire history, and only its sound structure has changed to a de- 
gree. The bolatin balatin data from the Founding Charter of the Benedictine Abbey of Tihany (1055) (SZENTGYÖRGYI 2010, pp. 23-24), are the earliest occurrences of the name of the Lake Balaton (which probably sounded like [bolatin] at the time). The hydronym is of Slavic origin in terms of its ultimate etymon (cf. Sl. *Blatbns 'muddy'). Hungarians borrowed this name from the Slavs. An important constraint that we can also ascertain in connection with settlement names of Slavic origin in early sources (e.g., Visegrád: < Slavic *Vyšegrad ‘ 'castle on a high ground', Csongrád: < Slavic *Čbrnъgradı 'black castle') applies to this name-form also, i.e., that it cannot be known when these places got their name as we have no access to relevant historical evidence. And this is certainly not a minor issue from the perspective of deciding on the chronological limits of the era when we can assume the presence of particular ethnic groups in the region (cf. KRISTÓ 2000, p. 20).

The Founding Charter of Tihany also includes the uluues megaia toponym (SzENTGYÖRGYI 2010, p. 25), which at the time would probably have sounded like [yj $\beta \varepsilon \int$ meja:ja]. In contemporary Hungarian this would be Ölyves megyéje and it indicates the boundary of the village of Ölyves through the use of Hungarian grammar: ölyv 'buzzard' + $-s$ 'adjective-forming suffix' / megye 'boundary' + -je 'Sg3 possessive suffix'. In this case it might emerge as a problem that the two lexemes in the name are loanwords in Hungarian. The word ölyv 'buzzard' was borrowed from Turkic languages, while megye 'boundary line' from one of the Slavic languages. Thus one of the central questions could be whether all this can influence our conclusions about linguistic affiliation of this name and also whether any conclusions can be drawn from it about the language (and ethnicity) of the name-givers.

The $\beta \varepsilon \sigma \pi \rho \dot{\varepsilon} \mu$ data in the Donation Charter of the Nunnery of Veszprémvölgy (prior to $1001 / 1109$; DHA 1, p. 85), which was probably pronounced [bespre:m] at the time, represents the typical example of settlement names that were created from a personal name of foreign (in this case Slavic) origin without a formant. ${ }^{2)}$ The name has survived to this day in an unchanged name structure, with only a phonetic change in the form of Veszprém. Although in this case it is obvious that the basic word of the settlement name is a personal name of Slavic origin, the manner of name-giving and the personal name $>$ settlement name metonymy clearly indicates Hungarian name-givers as in old Slavic languages settlement names were not formed from personal names without any formant. ${ }^{3)}$ This means that settlement names from Slavic personal names without formants give evidence of Hungarian name-givers. Whether from the Slavic origin of the personal name we can also deduce the presence of a Slavic population remains an open question.

\footnotetext{
2) The term formant in Hungarian historical toponomastics refers to those affix morphemes (primarily derivational suffixes) and lexical elements (geographical common nouns) that are used in Hungarian to express the role of toponyms.

3) Of the peoples living in the Carpathian Basin, during the Middle Ages only Hungarians created settlement names using personal names only, i.e., without adding any formants. In the languages of peoples living close to Hungarians this form of name-giving was unknown, they created toponyms from personal names either with affixes or with geographical common nouns. This means that irrespective of the etymology of the personal name, the personal name $>$ settlement name metonymy always indicates the presence of Hungarian name-givers.
} 
Finally, the settlement name Kér in the Charter of Veszprém preserves the name of an ethnic group, namely one of the conquering Hungarian tribes (1009/+1257: Cari villa; DHA 1, p. 52). There were 46 settlements named Kér in the Carpathian Basin during the Middle Ages (cf. Adatok 1, pp. 36-37), to which modifiers have been added subsequently to end the homonymous relationship between them. This settlement is called Hajmáskér today. (There are only 9 of these old Kér settlement names in today's Hungarian settlement name system; cf. FNESz.) There are lessons we can learn from this name beyond its own meaning: the settlement names containing the lexeme of a tribe's name mostly refer to the internal relations of the settlement even if such names were given by those living close to the given settlement. In this approach, the Kér settlement name can only be interpreted in a way that people from the Kér tribe lived in the settlement but not in its surroundings as this is the only way the name could fulfil its differentiating function (KRISTó 2000, p. 18). In such cases the question can mostly be whether there can be any ways of deciding who the givers of the settlement names could really be: those living in the given settlement or those living in its environment?

The problems detailed above in connection with these data in early charters raise several questions related to name theory both regarding place-naming and usage. These include questions on the reasons for name-giving and the basic circumstances of name genesis, as well as questions focusing on the status and function of toponyms. These will be addressed in what follows.

\section{The universal motives of place-naming}

The introduction to the key issues of name theory begins with an overview of the possible reasons behind place-naming, i.e., the usual motivations behind the aspirations of people to name a certain place. Earlier, the key reason for naming was explained as a way for people to orientate themselves in space and thus the important places are named. More recently, however, it is argued that the ultimate reason for name-giving is related to the communicative need of people, and the actual demand for a name is provided by the communicative needs emerging in a particular situation (HOFFMANN 2005, p. 120). Moreover, when talking about the causes of place-naming, we have to emphasise that cultural motivations also play a crucial role, as the name has been a fundamental part and universal component of human culture for thousands of years (HoFFMANN 2010b, p. 52). Thus naming itself is influenced by general conventions, so we give names also because it is customary to signify certain types of places with a proper name (HoFFMANN and TóTH 2016, pp. 262-263).

\section{Name competence and name patterns}

It is the underlying nature of name-giving that all naming acts are semantically conscious and follow existing name patterns, name models in a functional-semantic and lexical-morphological perspective. Semantic consciousness means that at the time of 
name-giving, one of the characteristics of the referent to be named appears in the name created, or there is some other semantic content connected to it; thus there is no absolutely unmotivated name. ${ }^{4)}$

The individual becomes familiar with toponyms as part of culture and language, in the process of social and linguistic socialisation. Simultaneously, they develop the ability to recognise and properly use particular names and also create new ones. Thus a kind of name competence develops in the process of socialisation, which also includes linguistic components besides cultural traditions and knowledge. Name competence is based on name patterns and name models, which includes the most basic cultural, pragmatic, semantic, and morphological knowledge about names. For name-givers, the name system that is known and used by them serves as the basis for new names in all cases, which prevails not only directly, by means of using the already existing names, but also indirectly, by means of the transmission of name patterns (cf. HoFFMANN 1993, p. 26; 2010b, p. 53; Hoffmann and Tóth 2016, p. 264; Ainiala et al. 2013, p. 75, 87; see also vaN LANGENDONCK 2007).

At the same time, modern socio-onomastic studies on toponyms have also revealed that semantic motivation and transparency are manifested in a contradictory manner from the perspective of name usage. These studies indicate that users of names consider the identifying function of names to be dominant, and the structure and semantic relationship of names with reality appear to be less significant for them. During socio-onomastic field work researchers have experienced that interviewees do not think about the motivational background of names even in the case of such words that can be identified with an obvious common word, just as they do not analyse the semantic and lexical structure of the name either: thus the name appears as a kind of a referential unit in their mind. Based on all this evidence, it seems that the users of names do not expect the names to reflect a semantic connection with reality, i.e., that they should be motivated in the actual sense of the word. This is probably also related to the fact that speakers are aware of and use several such toponyms, the original semantic content of which has become obsolete with time (cf. GYÖRFFY 2017, pp. 164-166). This would be consistent with Richard COATES' contention in various publications that the sense of any formants of a name is by definition extinguished at the moment at which a name is bestowed (COATES 2006a, 2006b, 2012).

\section{The socio-onomastic aspects of place-naming}

For a long time, it was thought that in the sociological background of place-naming the creation of names in olden times could only be imagined as being of folk nature and as a collective activity (for this approach cf. e.g. BENKö 1998, p. 112). Although some of the

\footnotetext{
4) However, there are very occasional documented names with no connection to any characteristic of the referent, not even a metonymic or other allusive connection, e.g., Truth, North Carolina, USA. George STEWART says concerning the name: "By local story, suggested in jest by a member of the selecting committee, and then adopted seriously" (CDAPN, p. 495).
} 
details of this approach may be accepted, it should be emphasised that this opinion is based on the idea that toponyms are selected randomly from the numerous unique common word designations related to a given place and that they slowly become proper names.

As opposed to this approach, however, in terms of the name-giving and name sociological situation, a differentiation should be made in terms of the emergence of the individual entities of particular toponym types. Name-giving is a complex and diverse process and the name-giving act should not be seen as a homogeneous phenomenon either, as it can be very varied due to the diversity of the communicative situation and that of the named places. This means that from the perspective of socio-onomastics, first of all, we have to differentiate between the naming acts of places and objects created by people (the socalled civilisational names, including settlement names mostly) and the name-giving acts occurring in the case of places existing independently of human presence (natural names, including the names of rivers, mountains, etc.) (HofFMAnN 2005, pp. 120-121; HofFMANN and TóTH 2016, pp. 264-265).

\subsection{Naming acts and civilisational names}

With settlement names, the cognitive-pragmatic approach focuses on the role of the individual, instead of the community, in the act of name-giving. Thus it places consciousness ahead of instinctiveness. Settlements are the creations of people and at the same time they also express that people took possession of a territory. The existence of the settlement is thus the result of human activity and name-giving can be perceived as part of this creative process. As a result, deliberateness and consciousness are present much more markedly in settlement name-giving, and individual interests are expressed more clearly than in the case of other toponym types; thus possibly more aspects of the naming act (e.g., the name-giver) may be seen (HoFFMANN 2005, p. 122; HoFFMANN and TóTH 2016, pp. 262).

Conscious name-giving means that the new name-forms are created mostly as a result of intentional and conscious mental processes and thus the act of settlement naming itself can be seen as the cognitive activity of the speakers. Therefore, in many cases names are given by the individual and not the community, but in a way that the new name fits into the naming system of the given name community and as a result the new language element can be accepted and used as a name by others as well. This onomastic interpretation thus perceives name-giving as an act and the former approach which focused on the gradual transformation of common word expressions into proper names is only considered a peripheral type of name-forming at most (HAJdú 2003, pp. 56-58; HoFFMANN 2014; HoFFMANN and TóTH 2016, pp. 265).

The conscious naming activity could be present at a much higher degree in the case of medieval settlement names than we have supposed earlier. We know more than one such charter passage, for example, in which the role of the owner in name-giving and changing is clearly present in the text as well (cf. e.g. KRISTó 1976, pp. 11-14). The data found in charters regarding the village of Marcelfalva [Marcel's/village] in Szatmár County demonstrate that originally it bore the name of Nógrád, certainly coming from Slavic name-givers. The settlement was, however, ravaged by a certain Marcel Radalfi (i.e., com- 
ing from settlement Radalf) who named it Marcelfalva after his own name. 1279: "villa Neugrad [...] quam quondam Marcellus nomine suo Marcelfoluua nuncupavit" (NÉMETH 2008, p. 176), meaning "The village of Neugrad [...] which was named Marcelfoluua by a certain Marcellus in his own name".

As charters were the most important documents of land ownership during the Middle Ages, they contain such references that shed light on name-giving either directly or indirectly. The largest amount of information about the name-giving process of the age is available in the sources in connection with the settlements named after people (it is not by accident that our examples so far also belong to this category). This indicates the prevalence of individual interests and this is where consciousness is most openly manifested in the name-giving process. Of course, there is a clear explanation for this in Hungarian language and culture, especially regarding the early centuries after the Conquest. Following the Conquest, the development and solidification of ownership lasted for centuries and it occurred at the borderline of the traditional oral and newly emerging written culture, where the latter was becoming increasingly important. Within the context of the oral tradition, the naming of the property could be an important means of expression of ownership itself, which could maintain an awareness of the association between the person and the place for a long time verbally (with the power of the word) in the life of the name-using community (due to its use in daily communication) (HoFFMANn 2005, p. 122; HofFMANN and Тóтн 2016, pp. 265-266; То́тн 2017; pp. 111-113).

\subsection{Naming acts and natural names}

In the case of natural names, conscious name-giving does not have such a significant role as in the case of settlement names. The weaker presence of the consciousness and deliberateness of name-givers can also be seen if we consider that sources rarely refer to acts of naming rivers, mountains or other natural objects. Having synonymous names is also rarer because the extra-linguistic circumstances influencing name-giving (e.g., social and psychological causes) do not really require the appearance of newer name variants. Nor is it irrelevant that natural names (especially microtoponyms) mostly function in a smaller circle of name-users than, for example, settlement names, and as a result of this they have a stronger local connection, which also determines the opportunities for their scholarly use. They are perfectly suitable for dialectological studies, especially because of these features, and they can also be considered in the case of studies of ethnic questions to a certain extent (HofFMAnN 2005, pp. 121-122; HofFMANN and Tóth 2016, p. 266).

\subsection{External or internal name-givers?}

This distinction regarding the sociological status of certain types of toponyms also questions the tenet that used to be provided as the only explanation and which considers the residents in the environment of the named settlement to be the main name-givers of the settlements: in terms of linguistic-ethnic consequences, this also means that the lin- 
guistic nature of the given settlement name primarily reveals information about the ethnic relations of the people nearby. Besides this approach, for a while now the idea that the exclusivity of the name-giving role of the neighbouring population cannot be viewed rigidly continues to attract attention.

However, we do not have to entirely dismiss the name-giving role of the neighboring population. For example, we can assume with great certainty in the case of settlement names deriving from ethnonyms (as in the case of a village inhabited by Besenyo people (Pechenegs) in a Hungarian environment) that it was certainly not the Pecheneg inhabitants themselves who gave the village the name Besenyo" 'Pecheneg'. In the case of other settlement names, however, we need to emphasise the role of the population of the settlement itself or one of its influential residents, its lord, etc. in name-giving which confirms the notion of conscious name-giving by an individual as seen in changes in the name that reflect a change of ownership or property rights. This is most likely the case in connection with toponyms deriving from anthroponyms but it is also highly possible that it was not the neighbouring population that played a key role in the creation of settlement names embodying the name of the place's patron saint like Szentistván 'St. Stephen' or Szentlászló 'St. Ladislaus' either, but rather the Church as an institution.

An indicator of conscious name-giving starting from an individual, for example, may be found in the changing processes which accompany a change of ownership or property rights on the level of language.

These changes obviously cannot be explained by communicative reasons as the identifying function related to the basic function of proper names had already been fully performed by the former name also. From the perspective of communication, the name change was mostly non-desirable as it resulted in uncertainty in communication. Thus with the creation of the new name, the name-giver even tolerated temporary difficulties in communication, which is obviously possible only if the name-giver had a clear interest in creating and using the new name.

Overall, this means that from the perspective of socio-onomastics, not only the natural and civilisational names, as types of toponyms, show great variance but within the latter group, the different settlement name types can be distinguished on the basis of linguistic principles; therefore, we cannot approach their genesis, changes, and linguistic features in an undifferentiated way either (for more details see HofFMANN and TóTH 2016, pp. 267-268).

\section{Name-givers and name-users}

The differentiation of place-name givers and name-users, the individual and the community is of crucial significance from the perspective of name theory. This should be emphasised especially because all of the language data that can be considered as the basis of the early linguistic (and also ethnic) study of the Carpathian Basin come from written sources and these sources (with rare exceptions) can shed some light not on name-giving but the circumstances of actual name usage. The act of naming itself might be separated by centuries from the time and linguistic status recorded by the charter and this has serious 
consequences on the linguistic and ethnic context. The bolatin $\sim$ balatin toponym of the Founding Charter of Tihany - which we have already mentioned - clearly indicates Slavic name-giving. We can state with certainty, however, that this denomination could not refer to a Slavic ethnic group in this part of Transdanubia in the middle of the $11^{\text {th }}$ century, when it was recorded in the form, as the users of the name were clearly Hungarians (due to the syllabic structure of the name). The original word-initial $b l$-consonant pair was extended into the form bal-with the addition of a vowel, as there was no such word-initial consonant cluster in Hungarian. When this name entered the Hungarian language, however, cannot be confirmed with the help of the tools of toponym and language history (HoFFMANN 2010a, pp. 49-50; HoFFMANN and TóTH 2016, p. 269).

\section{Toponyms and culture}

Also part of the linguistic evaluation of toponyms is the attempt to describe the exact usage value of these language elements in their complexity. Most people consider identification to be the most important role of proper names and within that category that of toponyms. As a result, toponyms may assume an identifying role even without any special knowledge of the context (which is not possible in the case of other identifying language tools), although in certain cases the clarifying role of the context might also be necessary. Toponyms, as linguistic signs, may express several functions and meanings. The toponyms, in our view, are among those language elements that have the richest meaning structure. Of the many meaning components, we will highlight those which have an important role in settlement name-giving. Cultural meaning can be considered a crucial component of the meaning structure of toponyms as proper names are characterised by their strong connection to culture, and much more so than any other language elements. Thus we might be able to fully grasp the role of names in communication only if we take the circumstance into consideration that name usage is just as much a cultural as a linguistic question. As a result, the name system has a fundamental connection not only with the language system but even more with culture, and the basic fault-lines of name systems are not along linguistic lines but mostly along cultural ones (HoFfMANN and Tóтн 2016, pp. 269-270). This aspect may be an important principle for the contrastive analysis of different toponymic systems. We would like to highlight the nature of cultural determination through the example of the Hungarian toponymic system.

Due to the fact that after their settlement in the Carpathian Basin the Hungarians integrated into European culture fully and took up the Christian faith, with the result that a new name type appeared not only in the system of personal names but also in the toponymic system which had the most intimate link with Christian culture, therefore, its emergence may only be understood in this context. In the system of personal names this cultural name type is represented by the category of religious personal names of Greek and Latin origin (e.g., Péter, Mihály, Márton, Mária, etc.), while in the case of the toponymic system by the settlement names referring to the patron saint of the church of the settlement (e.g., Szentpéter 'Saint Peter', Szentmihály 'Saint Michael', Szentmárton 'Saint Martin', Boldogasszony 'Our Lady', i.e., the 'Virgin Mary', etc.). The frequency of these settle- 
ment names was around $7 \%$ in medieval Hungary (every fourteenth or fifteenth settlement bore such a name, cf. Mezö 1996), while in the system of personal names Christian culture brought about an even more significant transformation: the Greek-Latin personal names have practically dominated Hungarian personal names given at the time of birth until the present day (cf. TóтH 2016, pp. 158-181).

The proper names that exhibit linguistic and cultural constraints and have an identifying function also play an important role in the development of the sense of identity of the individuals. The identity signifying function of names is most obviously manifested in the relationship of individuals and personal names but is also reflected in place-name use. Through giving, using, and modifying names the individuals continuously specify their role in the world: when, for example, they give a name to a place that has been unnamed before, practically speaking they create its identity but at the same time they build their own identity also by expressing their relationship to it (HoFfMANN and TóTH 2016, p. 270).

In the history of Hungarian names, a very strong identity-marking role has been associated with certain toponym types. This function is most prevalent in the case of the use of personal names in toponyms. The key function of name-giving of the Veszprém and Tihany settlement name type that have an identical form to personal names, was probably not to identify a place but more importantly to express the right to ownership and use of an area (HoFFMANN 2010b; То́тн 2017, pp. 111-113). However, the previously mentioned settlement names embodying the name of the place's patron saint were also spread in the Hungarian name system by the Church, as the most important basis for the transformation to Christian culture, in order to popularise the ideology represented by it and to form and reinforce a new type of individual and communal identity.

The functioning of toponyms as sources of various rights has been discussed several times in Hungarian scholarship: the question was mostly asked in the form of whether the name of an estate in itself could prove the legal title of ownership. Even though there has been criticism related to this view, claiming that a name cannot verify ownership rights, the legal role of toponyms still seems to be well founded in several respects. We should not disregard the fact that Hungarian society and culture in the age of Conquest were characterised by oral tradition and in certain areas of life (state administration, etc.) the use of written records pushed orality into the background only very slowly and gradually, over the centuries (SOLYMOSI 2006, p. 203). Under such circumstances the association between anthroponyms and toponyms could serve as an expression of the relationship between the person and the place in the form of customary law. The idea of toponyms serving as sources of law is also supported by the circumstance that in the oldest charters a large number of settlement names survived that are identical with personal names, serving as a good to the high productivity of this type of name-giving approach (TóTH 2017, pp. 111-113).

The dominance of settlement names with an identical form to personal names is well indicated by the following numbers: in the oldest Hungarian charter that has survived in its original form, the 1055 Founding Charter of Tihany Abbey, out of the 22 settlements and estates listed, 15 are name-forms identical to a personal name (68\%). In another comparison, we can see the great frequency of this name type among the settlement names of two medieval counties: in Abaúj and Bars counties, among the 616 settlement names from the 
early Old Hungarian period (895-1350), there are 172 such names that were formed from personal names without a formant $(28 \%)$.

\section{Conclusion}

In this part we provided a brief overview of the general questions of name theory that are connected to place-naming, usage, and changes and which are to be considered during the linguistic investigation of toponyms. We conclude by returning to the data from the $11^{\text {th }}$ century charters used as the starting point as well as to the key questions connected to them and identify those findings we can formulate in consideration of the issues in name theory.

Although the 1055: bolatin balatin data indicate Slavic name-givers (due to the name etymon), the sound structure of the name (the addition of an extra vowel to the original word-initial $b l$ - sound) clearly indicates Hungarian name-users in the area at the time of the writing of the Founding Charter of Tihany. Based on written sources, we have no information on the date of borrowing of the toponymic elements of foreign origin and their inclusion in the Hungarian name system. At most we can only gain insights into the name-using context of the age of the source. For this purpose, we rely on the principles of linguistic reconstruction methodology, the result of which can then serve as a basis for conclusions in terms of language and ethnicity (cf. HofFmann 2007, p. 14; HofFmanN and Tóтн 2016). The main tool of toponym reconstruction is toponym etymology itself, this, however, cannot be simplified to the specification of the ultimate etymon of the given name-form. Besides grasping the moment of name genesis, the etymologist also has to pay attention to the sources that have survived: as these data (being mostly elements referring to actual, living language use) also reveal the linguistic environment in which the given name appears, which is a crucial circumstance in terms of the chronology of toponym borrowings.

The two lexemes of the 1055: uluues megaia (Ölyves megyéje) toponym clearly make up a Hungarian possessive construction, expressed with Hungarian grammatical tools, and the first constituent also has a Hungarian derivational suffix. The linguistic origin of the lexemes making up the structure (one is of Turkish, the other of Slavic origin) cannot be associated with their appearance in the name, as the local name-givers undoubtedly used these words as the elements of Hungarian language in the process of name-giving. Thus based on the inclusion of these words in the names, we cannot conclude that there were other people (Turks, Slavs) living in the given area (HoFFmann 2010a, p. 105).

In connection with the name of Veszprém, in the process of the linguistic and ethnic evaluation of the settlement names that emerged without a formant from personal names of foreign (e.g., Slavic) origin we have to take into consideration that a conscious name-giving act was present more emphatically in the case of settlement names, which places the role of the individual into the foreground. This also means that the language features of the denomination also stand as witness mostly to the linguistic (and possibly ethnic) position of the person, and refer less to the linguistic-ethnic belonging of the neighboring population. At the same time, it should also be emphasised that - when pondering the linguistic and ethnic features of place-naming - the etymology of the personal name cannot be taken 
into consideration in connection with the early centuries. This proper name category (due to its characteristically strong cultural and social determination) cannot serve as the basis of linguistic and ethnic reconstruction in similar cases (HoFFMANN and Tóтн 2016, p. 272; Tóтн 2016, pp. 27-30).

With settlement names created from a tribe's name without a formant (we quoted the Cari [today's Kér]) data of the Charter of Veszprém from the $11^{\text {th }}$ century as an example) the name-giving role of the neighboring population is usually emphasised. But, when detailing the functional features of toponyms, we pointed out that one of the important functions of this type of name is its identity-signifying and identity-forming role. We, therefore, believe it to be a justified possibility that the naming of the villages referring to the names of tribes like Kér, Megyer, etc. indicates the naming activity of the inhabitants with at least the same likelihood as those names being given by the people living nearby. ${ }^{5)}$ Awareness of tribal affiliation could certainly be such a factor in the centuries following the Conquest that had a strong impact on the sense of identity of contemporary people (we might claim that for a while it could have the strongest influence of all) (HoFFMANN and Тóтн 2016, pp. 272-273).

\section{A Possible Toponym-Description Model}

\section{Functional linguistics background}

In the second part of our paper, we introduce the approach and theoretical framework used in our work on the system and history of Hungarian toponyms. First, we need to introduce those principles which we wish to follow in the analysis of toponyms (for more details see LadányI and Tolcsvai Nagy 2008; Hoffmann 2012). In the description of toponyms the functional approach is applied as we believe that functional linguistics may serve as the most suitable theoretical framework for toponomastics (and onomastics in general).

\subsection{The primacy of meaning}

This approach emphasises the unity of content and form, i.e., that of the meaning and phonetic form of toponyms, but meaning is considered to be primary in the operation

\footnotetext{
5) It is unlikely that the Kér and other settlement names formed from tribal names would have expressed not only the tribal belonging of those living there but also that of people in the area around the settlement. Besides differentiation from other settlements, the most important function of settlement names is identification. A settlement name of the Kér type cannot perform such functions if in the neighboring settlements there are also people living from the Kér tribe; similarly, a settlement inhabited by Germans may be called Német 'German' if in the area around it there are settlements not inhabited by Germans. This is an important general law of name-giving.
} 
of the name system. In the process of describing the name system we start out from the semantic component of the toponyms. The toponyms (and more broadly proper names) are language elements of rich and diverse meanings and their genesis is characterised by a high degree of semantic consciousness (or motivation in other words). In the meaning structure of toponyms the quality concepts which mostly appear are those which apply to the referent and are recognised in it. However, only one or two of these quality features are expressed in the linguistic form of the toponym (to be discussed in more detail later). As the same name may be constructed in different ways from the perspective of the name-giver both conceptually and semantically, the same place may be identified by several names. This is the basis for the cognitive explanation of toponymic synonymy.

A large forest in the northern part of the Hungarian language area in the Old Hungarian Era was named Nagy-erdö 'great/forest' based on its size and Bükk-erdö 'beech/forest' based on the typical tree type growing in it. At the same place, the name of the brook Egres pataka 'brook/with alders' indicates that there could be alder trees growing along it but as it ran through Bocsárd settlement it was also called Bocsárd pataka 'Bocsárd village's/ brook'. This kind of alternation revealed by historical sources, however, might only be apparent as the different denominations might be connected to different name-using communities.

Therefore, the semantic content expressed in the toponyms does not map the world directly but rather our knowledge of the world. Thus the motivation for names is not found in the world (in this case the places) but in the mind, the cognitive system of the name-using person.

\subsection{Empirical bases}

It is another important principle of toponomastics that it reaches valid typological findings through generalisation from empirical data, in an inductive way. Moreover, it searches not only for linguistic but also extra-linguistic explanations for the examined phenomena. Such data serve as the basis of abstraction and generalisation that always comes from actual and real language use. This requirement characterises both descriptive and historical toponomastics. From the very beginning Hungarian onomastic research has considered as its key task the collection of toponyms used in the language today and in earlier eras and to arrange them in databases. At the same time, it aims to develop those methodological processes which can help determine the actual contemporary linguistic usage value of names that have survived in various sources.

\section{The principles of toponym analysis}

The framework of toponymic analysis used in our work distinguishes between two approaches of inquiry: descriptive and historical analysis. Descriptive analysis primarily studies the structure of the toponym - but within this the functional-semantic and lexical-morphological approaches provide an opportunity for further differentiation (for more 
details see HoFFMANn 1993, 1999; TóTH 2001; RÁCz 2005; see also ŠRÁMEK 1972-1973; Kiviniemi 1975). The emphatic role of these aspects is due to the fact that names are linguistic signs and traditionally in their interpretation descriptive, constructional (containing both formal and functional components) and diachronic analyses have all played a crucial role.

This toponym descriptive framework is characterised by a high degree of differentiation: there are clearly-defined categories on each level of analysis, which possibly cover the full scope of name-formation methods; thus the category system developed this way may be suitable for the description of all types of toponyms and the name-formation processes and characteristics of all eras. We believe that ultimately name analysis is nothing else but the exploration of the regularities in place-names (their creation and functioning). And if we evaluate each name (as members of the toponym system) in the light of the rules, the totality of the names may also be presented in a systematic way. Therefore, in our opinion this toponym description framework can be used universally, i.e., for the description of the name systems of other languages. And as such it may also serve as a basis for comparative synchronic and diachronic studies.

\subsection{Types of toponyms}

The denotative meaning has a key role in the rich meaning structure of toponyms presented above, as this in itself already mirrors a kind of categorisation. This means that in case the name-users are aware of the denotative meaning of the place-name, then they are also familiar with the type of the given place (whether the name refers to a settlement, a river, a mountain, etc.). Very often, this type of categorisation is expressed in the toponyms linguistically as well: in name structures this role might be played by geographical common words (e.g., the patak 'brook', falu 'village', halom 'hillock' lexemes of the toponyms Rákos-patak 'a brook/rich in crayfish', Németfalu 'village/inhabited by Germans', Hegyes-halom 'pointed/hillock', etc. serve this function). The identification of toponym types is a primary task in the linguistic analysis of toponyms also, as this provides the basis for the further structural analysis of names. Thus a Sárospatak 'muddy brook' denomination can be described with a very different name structure if it names a brook than if it serves as the name of a settlement.

\subsection{The functional-semantic basis of name-giving}

All toponym-giving acts are semantically conscious. It means that at the time of their creation all toponyms are motivated. The name-giving and name-using individual or community creates new place-names by highlighting a feature or characteristic of the referent and adapting it to already existing name models. This presumption provides justification for the analysis of the functions expressed by toponyms. At the time of their creation, all names are semantically transparent and descriptive: the motifs and semantic categories serving as the basis of name-giving are present either directly or indirectly. 
The basic concept of functional-semantic analysis is the name constituent. Those units of a toponym are considered to be name constituents that express any semantic feature related to the referent at the time of the name genesis or during the functioning of the name. We also need to stress, however, that a name constituent function is not associated with each lexeme in the name. The name Mély-patak 'deep/brook' (as a hydronym), refers to such a type of water that is deep, while the name structure of Mély-patak-fö 'Mély-patak's/spring' expresses only two name constituent functions, i.e., 'the spring (1) of the brook named Mély-patak (2)'. Similarly, in the spring name Kék-kút 'blue/spring', two name constituents can be distinguished: its functional structure can be described as 'such a spring (1) where the color of the water is blue (2)'. The Kékkút settlement name that was created from it, however, includes only one name constituent as only one semantic feature is expressed in it, i.e., that the settlement 'lies next to a spring called Kék-kút". The above-mentioned Sáros-patak, as a river name, is a two-constituent name-form, semantically it means 'muddy/brook'; as a settlement name, however, Sárospatak has only one constituent and refers to '(a settlement) lying next to the brook named Sáros-patak'.

Toponyms may have a maximum of one or two constituents and the semantic features expressed in them can be categorised into three large semantic groups. (We use the / sign for the separation of the name constituents when it plays a role in the description of the semantic structure.)

The name constituents, on the one hand, can refer to the type of the place (e.g., Patak 'brook', Lak 'village', Kis/hegy 'small/mountain', Új/falu 'new/village') and on the other hand, the features of the given place can also be reflected in them. This latter group may include a lot of semantic features: it may express one of the characteristics of the place (its size, shape, color, etc.; e.g., Hosszú 'long', Nagy/erdö 'great/forest'; Teknö 'shell', Görbe/ ér 'curved/brook'; Kékes '(a mountain) of blue color', Fekete/erdő 'black/forest'); the relationship of the place to a certain external feature or circumstance (plant, animal, building, owner, etc.; e.g., Bükk '(a mountain) with beech trees', Nádas/patak 'reed/brook'; Csókás '(a place) with jackdaws', Sólyom/kő 'falcon/rock'; Szentistván '(a village) with a church consecrated in honor of St. Stephen', Malom/út 'a road/leading to a mill'; Petri '(a village which) belongs to Peter', Mihály/falva 'Michael's/village', etc.); or the relationship of the place to another place (e.g., a settlement, river, hill, etc.; as in Bocsárd/pataka 'the brook of/Bocsárd settlement', Tó/rét 'a field/lying next to a lake', Sólyom-kö/völgye 'the valley/next to a mountain called Sólyom-kö', etc.).

Besides these examples, there are also such name constituents whose only function is to name the place itself. These include such place-names, which were borrowed by one language from another (Duna, Balaton), and those where the place-names were used in another place-name (Berettyó/újfalu 'the place called Újfalu, which lies next to the river Berettyó').

Finally, we also need to consider the conventional function. Although it plays a peripheral role in place-naming as a whole, due to the great demand for place-names in modern times it is still a frequent name constituent function: it is customary in Hungary to name streets, for example, after famous people (Petöfi/utca 'Petöfi/street'), flowers (Ibolya/utca 'violet/street'), etc., but other types of toponyms might also get such names (e.g., Margit/ híd 'Margaret/bridge', Lenin/város 'Lenin/city'). 
The Hungarian toponymic system is characterised by the fact that single-component toponyms may be used in three types of semantic structures: in a toponym-type indicating (Type_i; e.g., the name of a hill Hegy 'hill'), designating (Design.; e.g. the settlement name Nógrád borrowed from Slavic languages), and descriptive (Descr.; e.g. the settlement name Péteri 'Peter's') function. In two-component names these semantic contents join each other, typically creating a Descr. + Type_i (e.g., the name of a brook Kis-patak 'small brook') or Descr. + Design. Structure (e.g., river name Kis-Duna 'small Duna'). The Design. + Type_i. structure is in a peripheral position in the name system. In Hungarian the core of the toponymic system is made up by two-component names with a Descr. + Type_i semantic structure.

The semantic basis of name-giving, i.e., the functional-semantic categories are not linguistic, language-specific categories but refer to extra-linguistic relations. The place-name created is influenced by reality in all cases: the referents motivate the created toponyms in a sense that their inherent characteristic features (reflected by people) are included as the basis of name-giving. Thus in comparing them we expect to see larger variance in the case of name cultures exhibiting major cultural differences (for more details see HoFFMANN 1993, pp. 43-54; То́тн 2001, pp. 131-163).

\subsection{The lexical-morphological basis of name-giving}

Of course, the toponymic system also has purely linguistic features: the lexical-morphological models are naturally language specific. All those linguistic means of expression may be included here (the set of linguistic elements and the rules for their connections), which can be used to create place-names in the language of a given time. The lexical-morphological models form a part of all languages, yet, in the use of the system of rules and the connected set of elements there are also differences. For example, in the majority of languages the use of personal names as lexical categories is a frequent phenomenon in name-giving (mostly to express possession), but there can be major differences between languages in terms of the morphological structures and name-formation rules used to create place-names from personal names.

The lexical basis of name-giving (corresponding to a certain extent with the semantic base) also includes three categories. There can only be geographical common nouns indicating a type of place on the lexical level and there can only be toponyms in a designating role. However, the function of indicating characteristic features can be performed by several language elements (and several parts of speech): besides the categories called "feature words" in the summary (which can include even word structures besides the various categories of nouns, adjectives, and numerals), geographical common nouns and toponyms can also play such a role as seen in the examples already mentioned.

Besides name constituents (or more precisely within them), we need to distinguish an additional unit for the lexical-morphological study of names: the name elements. By name elements we mean the lexemes included in the name and the formative elements performing a function in it. Thus in the above-mentioned Mély-patak-fö place-name, we can distinguish two name constituents and three name elements (mély 'deep' + patak 'brook' / 
$f_{o}^{\prime \prime}$ 'spring'), and in the Kék-kút spring name there are two name constituents and two name elements (kék 'blue' / kút 'spring'), while in the Kékkút settlement name the two name elements are featured only as a unit of a single name constituent (kék+kút). The separation of name elements within name constituents provides an opportunity for the fine-tuning of structural analysis (for more details see HoFFMANN 1993, pp. 55-58).

\subsection{Rules of place-name creation}

These two components of name-giving, the semantic and lexical bases have to be complemented with the name-formation rules in line with the description of the history of name-formation. As part of historical toponym analysis we study those linguistic rules with which the new toponyms are created and the forces that shape the integration of the language elements into the names. Among the rules of name-formation, the syntactic, morphological, and semantic rules represent the basic categories of name-giving.

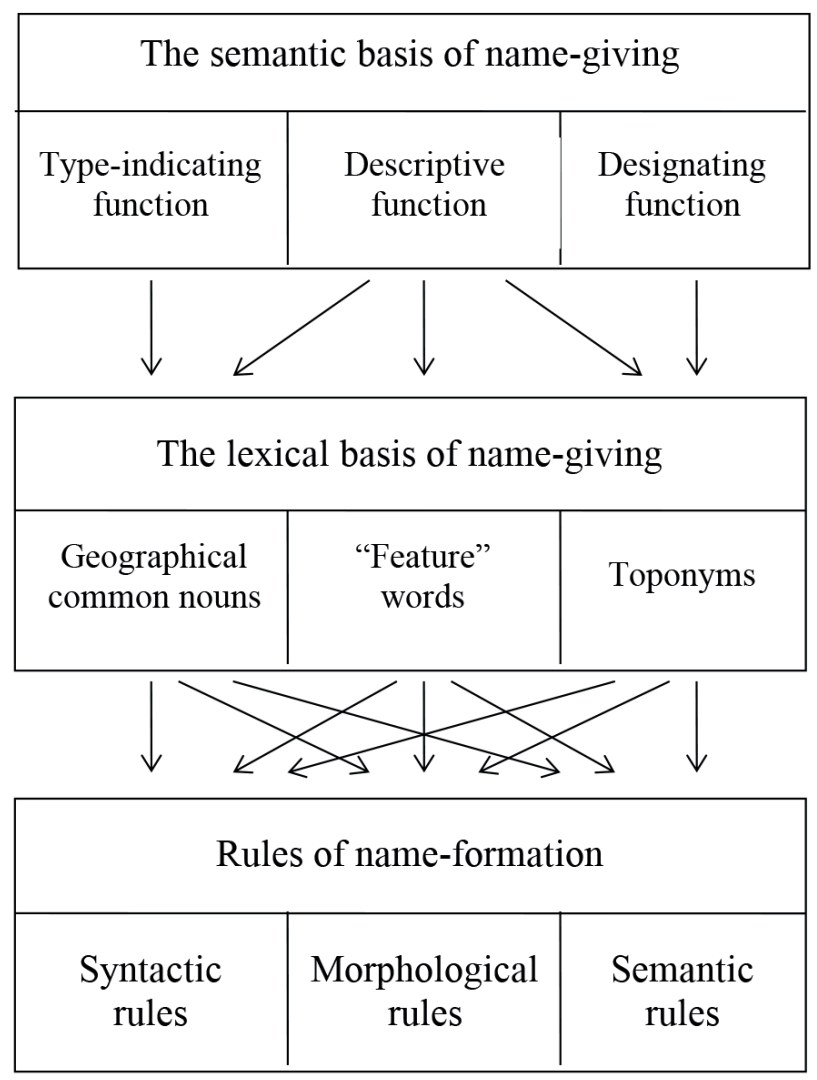

Figure 1: Correlations within the typological description of toponyms 
Due to the syntactic rules, in Hungarian mostly such toponyms are created that have an attribute or, more rarely, an adverbial structure (e.g., Kis-hegy 'small/hill', Három-halom 'three/hills', Pap rétje 'priest's meadow'). Morphological name-formation is primarily manifested as the formation of toponyms with derivational suffixes (e.g., Bükk ö-s: bükk 'beech' tree name $+-s$ derivational suffix, Német- $i$ : német 'German' ethnonym $+-i$ derivational suffix). As for the semantic rules, the three most frequent name-giving forms are metaphoric name-formation (e.g., Gatyaszár 'trouser-leg shaped [street]'), metonymic name-formation (e.g., Kér tribal name > Kér settlement name, Veszprém personal name $>$ Veszprém settlement name, bükk 'beech' tree name $>$ Bükk name of hill, horvát 'Croatian' ethnonym > Horvát settlement name, Sáros-patak hydronym > Sárospatak settlement name, etc.), and semantic split (e.g., from the geographical common nouns patak 'brook', eresztvény 'young forest', bérc 'mountain', liget 'grove', etc. the place-names Patak, Eresztvény, Bérc, Liget, etc.).

The relevant links between the semantic and lexical bases of name-giving and the rules of name-formation can be illustrated in Figure 1. The arrows pointing to the particular types of name-formation rules indicate that the elements of all the categories of the lexical base may, in theory, participate in any name-formation process (for more details see HoFFMANN 1993, pp. 67-143; 1999; TóTH 2001, pp. 165-230; 2008).

\section{Conclusion}

At the end of our study, we would like to highlight those areas that we believe to be the most adequate for international cooperation. Thus, we would like to introduce three opportunities for cooperation.

Already existing programs stand as witnesses to the effectiveness of international cooperation in the case of particular toponym types, especially settlement names: as a result of our project initiated with the purpose of exploring the European features of settlement names originated from the name of the place's patron saint, we published the book Patrociny Settlement Names in Europe in 2011 (edited by Valéria Tóтн). From the semantic categories, the study of settlement names formed from anthroponyms is also such an area that could reveal numerous universal and language-specific factors if investigated in a wider context (and in a wide range of languages).

Within civilisational names, the majority of settlement names may be categorised into three large semantic groups: first, there are some semantic types that are closely related to the human environment (including settlement names formed from personal names and names of social groups like ethnonyms, tribal names, and occupational names); secondly, there are those whose names denote the built environment (settlement names referring to castles, bridges, religious buildings, etc.), and thirdly, there are names designating the natural environment (settlement names referring to a location next to a body of water or a mountain, to the flora and fauna, etc.). Of these, the third settlement name type is the one most closely associated with natural names.

It is also a key principle in our paper that we have to make a clear distinction between civilisational and natural names in our linguistic and taxonomic analysis as different 
cognitive-pragmatic factors influenced both their genesis and changes. Within the group of natural names, names of watercourses provide the best opportunity for comparative studies. We believe that these categories should be considered in the comparative investigations of toponym types and categories as well and thus we will plan our international research programs in line with these. We do hope that onomasticians from different countries and language areas will also participate in these projects.

\section{References}

Adatok = Kristó Gy., MAKK F., Szegfü L. (1973, 1974): Adatok „korai” helyneveink ismeretéhez I-II [A Supplement to "early" Hungarian toponyms]. Szeged, József Attila Tudományegyetem Bölcsészettudományi Kar (= Acta Historica Szegediensis. Tomus XLIV., XLVIII).

Ainiala T., SaArelma M., Suöblom P. (2013): Names in Focus. An Introduction to Finnish Onomastics. Helsinki, Finnish Literature Society.

Benkő L. (1998): Név és történelem. Tanulmányok az Árpád-korról [Names and history. Studies of the Árpád era]. Budapest, Akadémiai Kiadó.

CDAPN = StewART G. (ed.) (1985): Concise Dictionary of American Place Names. Oxford, Oxford University Press.

Coates R. (2006a): Properhood. In: Language, 82, 2, pp. 356-382.

CoAtes R. (2006b): Some Consequences and Critiques of the Pragmatic Theory of Properhood. In: Onoma, 41, pp. 27-44.

CoAtes R. (2012): Eight Issues in the Pragmatic Theory of Properhood. In: Acta Linguistica Lithuanica, 66, pp. 119-140.

DHA = GYÖRFFY Gy. (1992): Diplomata Hungariae Antiquissima: accedunt epistolae et acta ad historiam Hungariae pertinentia, Vol. I. Budapest, Akadémiai Kiadó.

FNESz = KIss L. (1988): Földrajzi nevek etimológiai szótára I-II [Etymological dictionary of geographical names]. Fourth, extended and revised edition. Budapest, Akadémiai Kiadó.

GYőRFFY E. (2017): Helynévismeret és névközösség [Toponym awareness and name community]. In: Helynévtörténeti Tanulmányok, 13, pp. 155-169.

HAJDÚ M. (2003): Általános és magyar névtan. Személynevek [General and Hungarian onomastics. Personal names]. Budapest, Osiris Kiadó, pp. 17-150.

HoffMANN I. (1993): Helynevek nyelvi elemzése [The Linguistic analysis of toponyms]. Debrecen, Debreceni Egyetem Magyar Nyelvtudományi Tanszék. Second edition, Budapest, Tinta Kiadó, 2007.

HofFmann I. (1999): A helynevek rendszerének nyelvi leírásához [Supplement to the linguistic description of the system of toponyms]. In: Magyar Nyelvjárások, 37, pp. 207-216.

HofFmanN I. (2005): Régi helyneveink névadóinak kérdéséhez [Notes on name-givers of old Hungarian toponyms]. In: Névtani Értesítő, 27, pp. 117-124.

HofFmanN I. (2007): Nyelvi rekonstrukció - etnikai rekonstrukció [Linguistic reconstruction ethnic reconstruction]. In: HoffmAnN I., JuHÁsz D. (eds.): Nyelvi identitás és a nyelv dimenziói. Debrecen - Budapest, Nemzetközi Magyarságtudományi Társaság, pp. 11-20.

Hoffmann I. (2010a): A Tihanyi alapítólevél mint helynévtörténeti forrás [The Founding Charter of the Abbey of Tihany as a source in historical toponomastics]. Debrecen, Debreceni Egyetemi Kiadó (= A Magyar Névarchívum Kiadványai, 16).

Hoffmann I. (2010b): Név és identitás [Name and identity]. In: Magyar Nyelvjárások, 48, pp. $49-58$. 
HofFmann I. (2012): Funkcionális nyelvészet és helynévkutatás [Functional linguistics and toponomastics]. In: Magyar Nyelvjárások, 50, pp. 9-26.

HoffmanN I. (2014): Megjegyzések a személynevekkel azonos alakú helynevekről [Notes on toponyms with an identical form to personal names]. In: BÁRÁNY A., DresKa G., SzováK K. (eds.): Arcana tabularii. Tanulmányok Solymosi László tiszteletére. Budapest - Debrecen, Magyar Tudományos Akadémia, Debreceni Egyetem - Eötvös Loránd Tudományegyetem Bölcsészettudományi Kara, Pázmány Péter Katolikus Egyetem. I, pp. 693-704.

Hoffmann I., RÁcz A., Tóth V. (2017): History of Hungarian Toponyms. Hamburg, Buske.

HofFmann I., TóTH V. (2016): A nyelvi és az etnikai rekonstrukció kérdései a 11. századi Kárpát-medencében [Issues of linguistic and ethnic reconstruction in the Carpathian Basin during the $11^{\text {th }}$ century]. In: Századok, 150 , pp. 257-318.

Kiviniemi E. (1975): Paikannimien rakennetyypeistä [On structural types of place names]. Helsinki, Suomalaisen Kirjallisuuden Seura.

KrisTó Gy. (1976): Szempontok korai helyneveink történeti tipológiájához [Considerations for the historical typology of early Hungarian toponyms]. Szeged (= Acta Historica Szegediensis. Tomus LV).

KRISTó Gy. (2000): Magyarország népei Szent István korában [Ethnic groups in Hungary in the period of St. Stephen]. In: Századok, 134, pp. 3-44.

LadÁnyi M., Tolcsvai Nagy G. (2008): Funkcionális nyelvészet [Functional Linguistics]. In: Általános Nyelvészeti Tanulmányok, 22, pp. 17-58.

Mező A. (1996): A templomcím a magyar helységnevekben. 11-15. század [Patrocinies in Hungarian settlement names. $11^{\text {th }}-15^{\text {th }}$ century]. Budapest, METEM (= METEM-könyvek, 15).

NÉMETH P. (2008): A középkori Szatmár megye települései a XV. század elejéig [The settlements of medieval Szatmár County until the beginning of the $15^{\text {th }}$ century]. Nyíregyháza, Jósa András Múzeum (= A Nyíregyházi Jósa András Múzeum Kiadványai, 60).

RÁcz A. (2005): A régi Bihar vármegye településneveinek nyelvészeti vizsgálata [The linguistic study of the settlement names of historical Bihar County]. Debrecen, Debreceni Egyetem Magyar Nyelvtudományi Tanszék (= A Magyar Névarchívum Kiadványai, 9).

Solymosi L. (2006): Írásbeliség és társadalom az Árpád-korban [Written culture and society in the Árpád Era]. Budapest, Argumentum Kiadó.

ŠrameK R. (1972-1973): Zum Begriff „Modell” und „System” in der Toponomastik. In: Onoma, 17 , pp. 55-75.

SzENTGYÖRGYI R. (2010): A Tihanyi alapítólevél szövege [The text of the Founding Charter of the Abbey of Tihany]. In: Hoffmann I.: A Tihanyi alapítólevél mint helynévtörténeti forrás (= A Magyar Névarchívum Kiadványai, 16). Debrecen, Debreceni Egyetemi Kiadó, pp. 21-41.

То́тн V. (2001): Névrendszertani vizsgálatok a korai ómagyar korban [Onomatosystematical analyses in the Early Old Hungarian Era]. Debrecen, Debreceni Egyetem Magyar Nyelvtudományi Tanszék (= A Magyar Névarchívum Kiadványai, 6).

То́тн V. (2008): Településnevek változástipológiája [Change Typology of Settlement Names]. Debrecen, Debreceni Egyetem Magyar Nyelvtudományi Tanszéke (= A Magyar Névarchívum Kiadványai, 14).

То́тн V. (2016): Személynévadás és személynévhasználat az ómagyar korban [Personal name-giving and personal name-usage in the Old Hungarian Era]. Debrecen, Debreceni Egyetemi Kiadó (= A Magyar Névarchívum Kiadványai, 38).

То́тн V. (2017): Személynévi helynévadás az ómagyar korban [Toponyms based on anthroponyms in the Old Hungarian Era]. Debrecen, Debreceni Egyetemi Kiadó (= A Magyar Névarchívum Kiadványai, 41). 
Tо́тн V. (ed.) (2011): Patrociny Settlement Names in Europe. Debrecen-Helsinki, Debrecen University Press (= Onomastica Uralica, 8).

van Langendonck W. (2007): Theory and Typology of Proper Names. Berlin - New York, Mouton de Gruyter (= Trends in Linguistics. Study and Monographs, 168). 